\title{
KIR gene content diversity in four Iranian populations
}

\author{
Elham Ashouri • Shirin Farjadian • Elaine F. Reed • \\ Abbas Ghaderi • Raja Rajalingam
}

Received: 17 March 2009/Accepted: 20 May 2009/Published online: 12 June 2009

(C) The Author(s) 2009. This article is published with open access at Springerlink.com

\begin{abstract}
Killer cell immunoglobulin-like receptors (KIR) regulate natural killer cell response against infection and malignancy. KIR genes are variable in the number and type, thereby discriminating individuals and populations. Herein, we analyzed the KIR gene content diversity in four native populations of Iran. The KIR genomic diversity was comparable between Bakhtiari and Persian and displayed a balance of A and B KIR haplotypes, a trend reported in Caucasian and African populations. The KIR gene content profiles of Arab and Azeri were comparable and displayed a preponderance of $B$ haplotypes, a scenario reported in the natives of America, India, and Australia. A majority of the B haplotype carriers of Azeri and Arab had a centromeric gene-cluster (KIR2DS2-2DL2-2DS3-2DL5). Remarkably, this cluster was totally absent from the American natives
\end{abstract}

Electronic supplementary material The online version of this article (doi:10.1007/s00251-009-0378-7) contains supplementary material, which is available to authorized users.

E. Ashouri $\cdot$ E. F. Reed $\cdot$ R. Rajalingam $(\triangle)$

UCLA Immunogenetics Center,

Department of Pathology and Laboratory Medicine,

David Geffen School of Medicine at UCLA,

University of California at Los Angeles,

1000 Veteran Avenue, Room \# 1-536, Box 951652, Los Angeles,

CA 90095-1652, USA

e-mail: rrajalingam@mednet.ucla.edu

E. Ashouri $\cdot$ A. Ghaderi $(\triangle)$

Shiraz Institute for Cancer Research,

Shiraz University of Medical Sciences,

P.O. Box 71345-1798, Shiraz, Iran

e-mail: ghaderia@sums.ac.ir

S. Farjadian

Department of Immunology,

Shiraz University of Medical Sciences,

Shiraz, Iran but occurred at highest frequencies in the natives of India and Australia in combination with another gene cluster at the telomeric region (KIR3DS1-2DL5-2DS5-2DS1). Therefore, despite having similar frequencies of B haplotypes, the occurrence of B haplotype-specific KIR genes, such as $2 D L 2$, 2DL5, 3DS1, 2DS1, 2DS2, 2DS3, and 2DS5 in Azeri and Arab were substantially different from the natives of America, India, and Australia. In conclusion, each Iranian population exhibits distinct KIR gene content diversity, and the Indo-European KIR genetic signatures of the Iranians concur with geographic proximity, linguistic affinity, and human migrations.

Keywords NK cells $\cdot$ KIR genes · Immunity-related genes · Polymorphism $\cdot$ Iranian populations $\cdot$ Persian

\section{Introduction}

Natural killer (NK) cells are fast-acting lymphocytes that provide the first line of defense against infection and tumor transformation (Trinchieri 1989). Human NK cells largely use killer cell immunoglobulin-like receptors (KIR) to distinguish the unhealthy targets from the healthy self (Lanier 2005). A family of 16 homologous genes clustered at the leukocyte receptor complex on chromosome 19q13.4 encodes KIR receptors (Vilches and Parham 2002; Wilson et al. 2000). Fourteen of them encode receptors that trigger either inhibition (3DL1-3, 2DL1-3, and 2DL5) or activation (3DS1, 2DS1-2DS5) or both (2DL4) and two pseudogenes (2DP1 and 3DP1) that do not encode a cell-surface receptor. The inhibitory KIRs recognize distinct motifs of HLA class I molecules and trigger signals that stop NK cell function, while the ligands for the activating KIRs are unknown. Epidemiological studies suggest that the activating KIRs may recognize pathogen-derived or pathogen-induced 
cell surface determinants and trigger NK response against the unhealthy targets, which may yield immunopathology or resistance to infection (Khakoo and Carrington 2006).

The number and type of KIR genes vary substantially between haplotypes and display sequence polymorphism (Hou et al. 2008; Hsu et al. 2002; Martin et al. 2004; Middleton et al. 2007; Shilling et al. 2002; Whang et al. 2005; Wilson et al. 2000). On the basis of gene content, KIR haplotypes are broadly classified into two groups (Uhrberg et al. 1997). Group A haplotypes have a fixed gene content comprising KIR3DL3-2DL3-2DP1-2DL13DP1-2DL4-3DL1-2DS4-3DL2 but are diversified through allelic polymorphism of the individual genes. In contrast, group B haplotypes have variable gene content comprising several genes and alleles that are not part of the A haplotype. Particularly, KIR2DS1, 2DS2, 2DS3, 2DS5, $2 D L 2,2 D L 5$, and $3 D S 1$ are associated only with group B haplotypes, and thus $\mathrm{B}$ haplotypes generally encode more activating KIR receptors than the A haplotype that encodes a single activating receptor, KIR2DS4. Four framework genes (KIR3DL3, 3DP1, 2DL4, and 3DL2) are conserved on both $\mathrm{A}$ and $\mathrm{B}$ haplotypes and therefore ubiquitously present in all individuals.

All human populations have both group $\mathrm{A}$ and $\mathrm{B}$ haplotypes, but their frequencies vary considerably (Parham 2005; Single et al. 2007; Yawata et al. 2002a). In Africans and Caucasians, the $\mathrm{A}$ and $\mathrm{B}$ haplotypes are equally distributed, suggestive of a balancing selection. Conversely, the A haplotype is overrepresented in Northeast Asians (Chinese, Japanese and Koreans), while the $B$ haplotype occurred most frequently in the natives of India, Australia, and America (Ewerton et al. 2007; Flores et al. 2007; Gendzekhadze et al. 2006; Jiang et al. 2005; Norman et al. 2002; Rajalingam et al. 2002; Toneva et al. 2001; Whang et al. 2005; Yawata et al. 2002b). Herein, we investigated the KIR gene content diversity in four native populations of Iran, a country with central geographic location which served as a gateway of human movements during the past 60,000 years.

\section{Materials and methods}

Study subjects and DNA extraction

A total of 504 unrelated individuals belonging to four native populations of Iran were included in this study (Fig. 1). Persian people $(n=248)$, who speak Persian as their primary language, live in Fars province. Azeri people $(n=84)$ live in East Azerbaijan province and speak Turkic language. Bakhtiari people $(n=96)$ live in Khuzestan province and speak Luri, a dialect of Persian language. Arab people $(n=76)$ live in Khuzestan province and speak

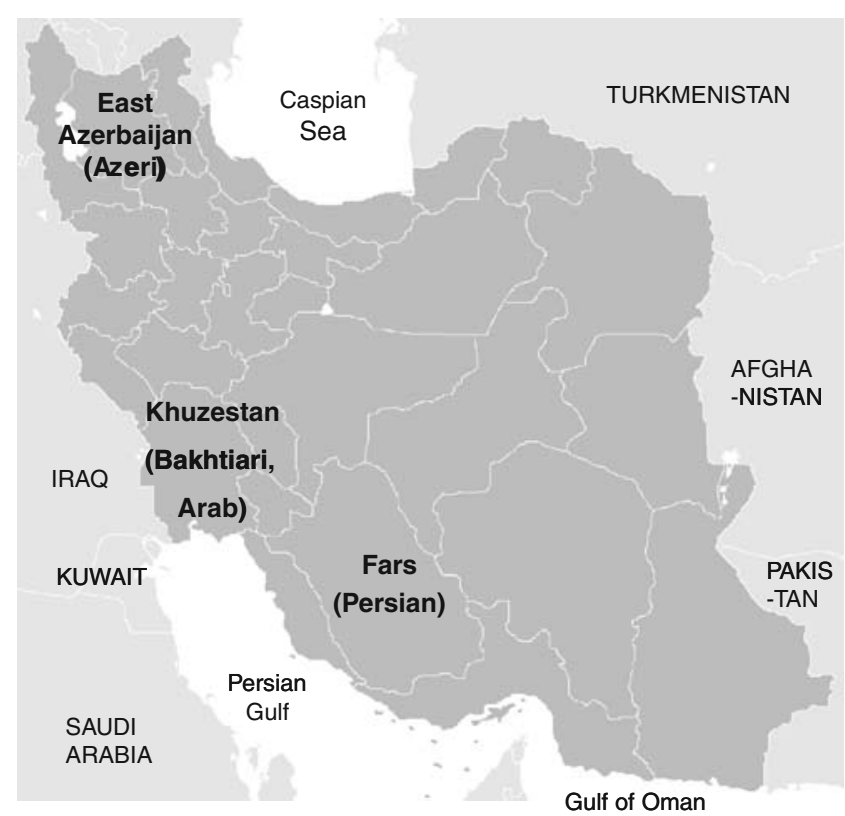

Fig. 1 Map of Iran showing the provinces of four study populations. DNA samples of Persian population were collected from Fars province, Azeri were collected from East Azerbaijan province, and Bakhtiari and Arab were collected from Khuzestan province

Arabic. The study was reviewed and approved by the appropriate Institutional Review Boards of human research protection. Genomic DNA was extracted from peripheral blood samples using either standard salting out method or by QIAamp blood kit (Qiagen, Hilden, Germany). The quality and quantity of DNA samples were determined by UV spectrophotometry, and the concentration was adjusted to $100 \mathrm{ng} / \mu \mathrm{L}$.

\section{KIR genotyping}

The presence and absence of 16 distinct KIR genes was determined using our recently developed duplex sequencespecific priming-based polymerase chain reaction (SSPPCR) typing system (Ashouri et al. 2009). The unique and unusual KIR genotypes were further confirmed by re-typing using our alternative SSP-PCR typing method (Du et al. 2007). Both of the typing methods were validated extensively using the UCLA International KIR exchange reference DNA samples, which provided identical KIR genotyping results, indicating that the specificity and sensitivity of the two methods were comparable (Ashouri et al. 2009).

The KIR genotyping data of world populations used for comparison in this study was extracted from the following publications: Han Chinese (Jiang et al. 2005), Korean (Whang et al. 2005), Japanese (Yawata et al. 2002b), Vietnamese, Australian Aborigine (Toneva et al. 2001), Thai, British Caucasian, Palestinian Arab (Norman et al. 2001), Warao, Bari, Yucpa (Gendzekhadze et al. 2006), Australian Caucasian (Witt et al. 1999), New York Caucasian (Hsu et al. 2002), Finnish, French Caucasian, Senegal African, 
Guadeloupe Caribbean, and Reunion, a population from Indian Ocean origin (Denis et al. 2005), American Caucasian, Hispanic, African American (Du et al. 2007), Greek (Niokou et al. 2003), Afro-Caribbean, Trinidad Asian, Pakistani (Norman et al. 2002), North Indian (Rajalingam et al. 2002), Chinese, Malay and Indian migrants in Singapore (Lee et al. 2008), Parsi and Maharastrian of India (Kulkarni et al. 2008), Paravar, Kanikar, Mollukurumba (Rajalingam et al. 2008), Basque population (Santin et al. 2006), Cook Island, Samoan, Tokelau, Tongan (Velickovic et al. 2006), Mestizo, Huichol, Purepecha, Tarahumara (GutierrezRodriguez et al. 2006), Northern Irish (Middleton et al. 2007), Wichis and Chiriguanos (Flores et al. 2007), and Amazonian Amerindian (Ewerton et al. 2007).

Prediction of haplogroups from genotypes

$K I R$ gene content of a given individual is conventionally called "KIR genotype," which is variable among individuals. The KIR gene content was used to infer group A and B KIR haplotypes and to assign each person to one of three genotypes: $\mathrm{AA}, \mathrm{BB}$, and $\mathrm{AB}$. Individuals having only genes of the group A KIR haplotypes (KIR3DL3-2DL3-2DL12DP1-3DP1-2DL4-3DL1-2DS4-3DL2) were considered to be homozygous for the A haplotype and assigned the KIR genotype AA. Individuals lacking any of the four A haplotype associated genes (KIR2DL1, 2DL3, 3DL1, and 2DS4) that have a known function and vary among individuals in their existence were regarded to be homozygous for group $\mathrm{B}$ haplotypes and assigned the KIR genotype BB. All other individuals were regarded to be heterozygous for $\mathrm{A}$ and $\mathrm{B}$ haplotypes and assigned the KIR genotype AB. The individuals with $\mathrm{AB}$ genotypes had all nine genes present on the $\mathrm{A}$ haplotype, as well as one or more $\mathrm{B}$ haplotype specific genes (2DL2, 2DL5, 2DS1, 2DS2, 2DS3, 2DS5, and 3DS1). The AB and $\mathrm{BB}$ genotypes were previously referred together as KIR genotype Bx (McQueen et al. 2007).

Classification of genotypes on the basis of centromeric and telomeric gene clusters

Based on the linkage disequilibrium, we recognized two frequently occurring gene clusters (Du et al. 2008). One cluster comprises KIR2DS2-2DL2-2DS3-2DL5 genes and is

Table 1 Comaprison of carrier frequency of KIR genes in four Iranian populations

\begin{tabular}{|c|c|c|c|c|c|c|c|c|c|c|}
\hline \multirow[t]{2}{*}{ KIR } & \multirow{2}{*}{$\begin{array}{l}\text { Persian } \\
\text { (Per) } \\
n=248\end{array}$} & \multirow{2}{*}{$\begin{array}{l}\text { Bakhtiari } \\
\text { (Bak) } \\
n=96\end{array}$} & \multirow{2}{*}{$\begin{array}{l}\text { Arab (Arb) } \\
n=76\end{array}$} & \multirow{2}{*}{$\begin{array}{l}\text { Azeri (Aze) } \\
n=84\end{array}$} & \multicolumn{6}{|c|}{$p$ values } \\
\hline & & & & & $\begin{array}{l}\text { Per vs. } \\
\text { Bak }\end{array}$ & $\begin{array}{l}\text { Per vs. } \\
\text { Arb }\end{array}$ & $\begin{array}{l}\text { Per vs. } \\
\text { Aze }\end{array}$ & $\begin{array}{l}\text { Bak vs. } \\
\text { Arb }\end{array}$ & $\begin{array}{l}\text { Bak vs. } \\
\text { Aze }\end{array}$ & $\begin{array}{l}\text { Arb vs. } \\
\text { Aze }\end{array}$ \\
\hline & $\% \mathrm{~F}(N)$ & $\% \mathrm{~F}(N)$ & $\% \mathrm{~F}(N)$ & $\% \mathrm{~F}(N)$ & & & & & & \\
\hline \multicolumn{11}{|c|}{ A haplotype associated $K I R$ genes } \\
\hline $2 D L 1$ & $98.0(244)$ & $94.8(91)$ & $100(76)$ & $98.0(83)$ & & & & & & \\
\hline $2 D L 3$ & $91.0(226)$ & $89.6(86)$ & $89.5(68)$ & $89.2(75)$ & & & & & & \\
\hline $3 D L 1$ & $94.0(238)$ & $95.8(92)$ & $85.5(65)$ & $90.5(76)$ & & & & & & \\
\hline $2 D S 4$ & $96.0(239)$ & $97.9(94)$ & $98.7(75)$ & $98.8(83)$ & & & & & & \\
\hline \multicolumn{11}{|c|}{ B haplotype associated $K I R$ genes } \\
\hline $2 D L 2$ & $56.8(141)$ & $54.1(52)$ & $63.1(48)$ & $67.9(57)$ & & & & & & \\
\hline $2 D L 5$ & $58.0(144)$ & $54.1(52)$ & $67.1(51)$ & $73.8(62)$ & & & 0.013 & & 0.0083 & \\
\hline $3 D S 1$ & $33.0(83)$ & $45.8(44)$ & $42.1(32)$ & $38.0(32)$ & 0.035 & & & & & \\
\hline $2 D S 1$ & $35.0(89)$ & $42.7(41)$ & $44.7(34)$ & $39.2(33)$ & & & & & & \\
\hline $2 D S 2$ & $54.0(135)$ & $49.0(47)$ & $56.3(49)$ & $70.2(59)$ & & & 0.015 & 0.046 & 0.0041 & \\
\hline $2 D S 3$ & $38.3(95)$ & $27.1(26)$ & $50.0(38)$ & $53.5(45)$ & & & 0.015 & 0.0025 & 0.0004 & \\
\hline $2 D S 5$ & $25.4(63)$ & $39.6(38)$ & $35.5(27)$ & $34.5(29)$ & 0.012 & & & & & \\
\hline \multicolumn{11}{|c|}{ Framework genes/pseudogenes } \\
\hline $2 D L 4$ & $100(248)$ & $100(96)$ & $100(76)$ & $100(84)$ & & & & & & \\
\hline $3 D L 2$ & $100(248)$ & $100(96)$ & $100(76)$ & $100(84)$ & & & & & & \\
\hline $3 D L 3$ & $100(248)$ & $100(96)$ & $100(76)$ & $100(84)$ & & & & & & \\
\hline $2 D P 1$ & $98.0(243)$ & $96.9(93)$ & $98.7(75)$ & $100(84)$ & & & & & & \\
\hline $3 D P 1$ & $100(248)$ & $100(96)$ & $100(76)$ & $100(84)$ & & & & & & \\
\hline
\end{tabular}

Frequency $(\% \mathrm{~F})$ of carriers of each gene is expressed as a percentage and defined as the number of individuals carrying the gene $(N)$ divided by the number of individuals studied $(n)$ in the given population group. The $p$ values are given only for those pairwise comparisons indicating significant $(<0.05)$ differences 


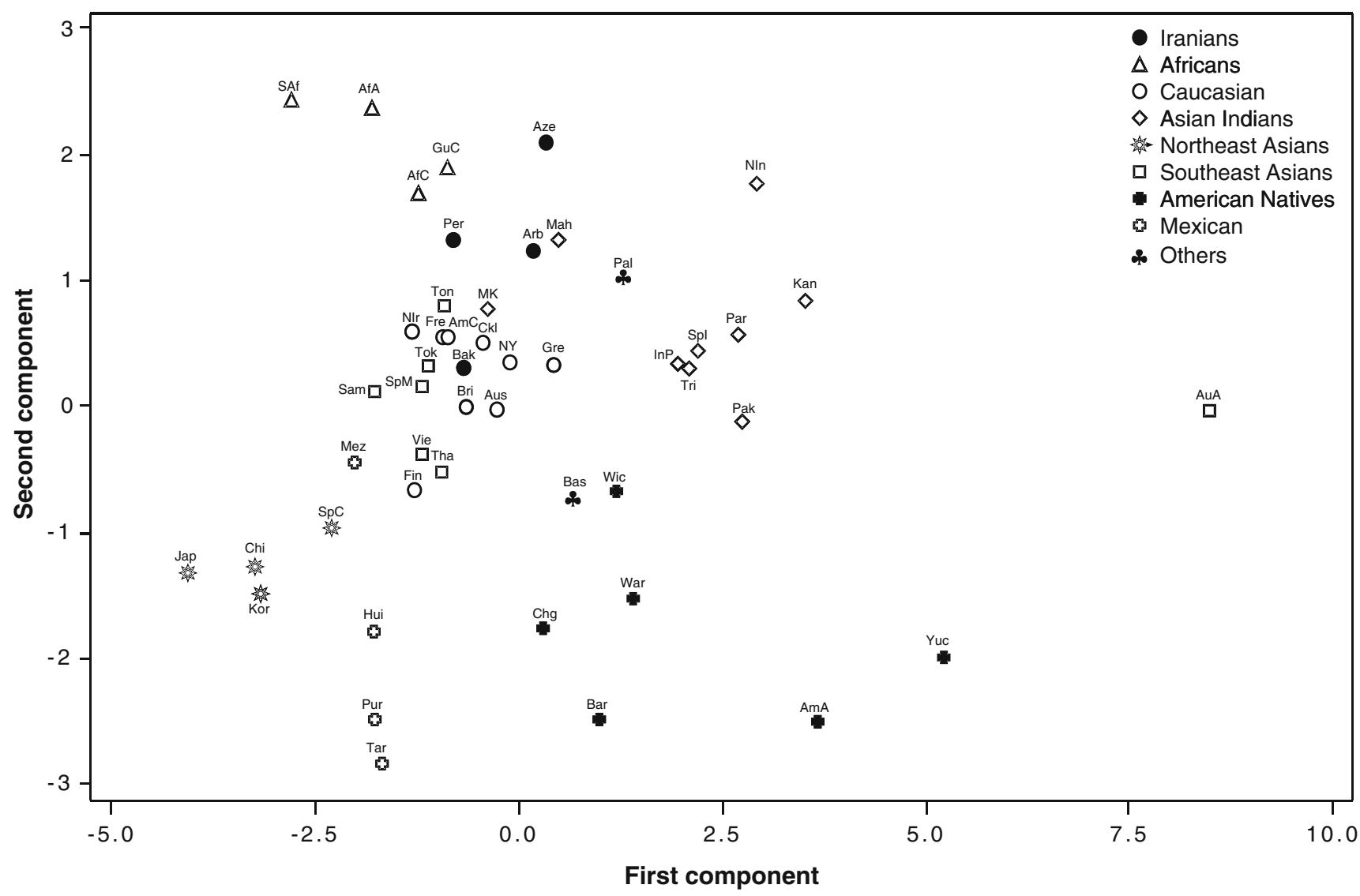

Fig. 2 Principal component analysis (PCA) of carrier frequency of nine variable $K I R$ genes. The PCA graph built upon the frequencies of individuals carrying nine variably occurring $K I R$ genes (2DL1-3, $2 D S 1-4,3 D L 1$, and $3 D S 1$ ) shows a global view relationship between the four Iranian populations studied in this paper and other previously reported world populations. The other seven genes $(2 D L 5,2 \mathrm{DS} 5$, $2 D L 4,3 D L 2,3 D L 3,2 D P 1$, and $3 D P 1$ ) were excluded from the analysis because they were either invariably present in all individuals or not typed in some populations. Jap Japanese, Chi Han Chinese, Kor Korean, SpC Singapore Chinese, Hui Huichol, Pur Purepecha, Tar Tarahumara, Chg Chiriguanos, Wic Wichis, War Warao, Bar Bari, AmA Amazonian Amerindian, Yuc Yucpa, Vie Vietnamese, Tha Thai,
Reu Reunion, Gre Greek, CkI Cook Island, Sam Samoan, Tok Tokelau, Ton Tongan, Mez Mestizo, Bri British Caucasian, Aus Australian Caucasian, NIr Northern Irish, $N Y$ New York Caucasian, Fin Finnish, Fre French Caucasian, AmC American Caucasian, SpM Singapore Malay, His Hispanic, $M K$ Mollukurumba, SAf Senegal African, $G u C$ Guadeloupe Caribbean, AfA African American, $A f C$ Afro-Caribbean, Per Persian, Bak Bakhtiari, Arb Iranian Arab, Aze Azeri, Pal Palestinian Arab, Mah Maharashtrian, Tri Trinidad Asian, Pak Pakistani, NIn North Indian, Par Paravar, Kan Kanikar, InP Indian Parsi, Bas Basque population, SpI Singapore Indians, AuA Australian Aborigine located at the centromeric half of the KIR gene complex, while another cluster comprises KIR3DS1-2DL5-2DS1$2 D S 5$ genes and is located at the telomeric half of the complex. For simplicity, we call these clusters C4 and T4, in which " $\mathrm{C}$ " represents centromeric, " $\mathrm{T}$ " represents telomeric, and " 4 " indicates the number of genes. On the basis of the presence and absence of $\mathrm{C} 4$ and $\mathrm{T} 4$ clusters, the $\mathrm{Bx}$ genotypes were further divided into the following four subsets: C4Tx (presence of C4 and absence of T4), CxT4 (absence of $\mathrm{C} 4$ and presence of T4), C4T4 (presence of both $\mathrm{C} 4$ and T4), and CxTx (absence of both $\mathrm{C} 4$ and T4). These Bx subsets were substantially variable in activating KIR gene content.
Fig. 3 KIR gene content diversity of Iranian populations. Within 504 unrelated individuals representing four linguistic Iranian populations, 78 genotypes that differed by the presence (shaded box) and absence (white box) of 16 KIR genes were observed. The frequency of each genotype is presented in percentage frequency $(\% \mathrm{~F})$ and defined as the number of individuals carrying the genotype $(N)$ divided by the number of individuals studied $(n)$ in the given population. Genotypes with identical gene content listed in this figure and in the Supplementary Figure 1a, b are marked with the same number. Unique genotypes that were not reported from other ethnic populations are identified by asterisk. Based on the gene content, genotypes were grouped as we described in the text. The genotypes that significantly differed $(p<0.05)$ among Iranian populations are marked by dark boxes: genotypes 1 (Persian vs. Arab, $p=0.035$, Persian vs. Azeri, $p=0.013$ ), 5 (Bakhtiari vs. Azeri, $p=0.044$ ), 10 (Persian vs. Arab, $p=0.041$ ), 12 (Persian vs. Bakhtiari, $p=0.041$ ), 94 (Persian vs. Arab, $p=0.041$ ) 


\begin{tabular}{|c|c|c|c|c|c|c|c|c|c|c|c|c|c|c|c|c|}
\hline & & & & & & & & & & $\mathrm{IRg}$ & jene & & & & & \\
\hline & enoty & & Grou & ap-A $\mathrm{p}$ a & $\begin{array}{l}\text { laplot } \\
\text { iated }\end{array}$ & & & roup-t & B hapl & lotype & $e$ ass & sociat & & & & $\begin{array}{l}\text { amewc } \\
\text { edoge }\end{array}$ \\
\hline 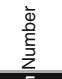 & 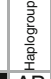 & 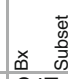 & ลิे & $\begin{array}{l}\text { à } \\
\text { â. }\end{array}$ & बें & $\begin{array}{l}\text { Dे } \\
\text { ปे }\end{array}$ & $\begin{array}{l}\tilde{\omega} \\
\text { ని }\end{array}$ & ปิ & $\begin{array}{l}\text { Dे } \\
\text { הి }\end{array}$ & $\begin{array}{l}n \\
\text { ẫ } \\
\text { | }\end{array}$ & $\begin{array}{l}\text { के } \\
\text { p. }\end{array}$ & $\begin{array}{l}\text { } \\
\text { ลे } \\
\text {. }\end{array}$ & ஸे & 令 & 命 & 㐫 \\
\hline 5 & $A B$ & C4TX & & & & & & & & & & & & & & \\
\hline 7 & $A B$ & C4Tx & & & & & & & & & & & & & & \\
\hline 11 & $A B$ & C4TX & & & & & & & & & & & & & & \\
\hline 10 & $A B$ & C4Tx & & & & & & & & 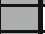 & & & & & & \\
\hline $36^{*}$ & $A B$ & C4TX & & & & & & & & $\square$ & & & & & & \\
\hline $61^{*}$ & $A B$ & C4Tx & & & & & & & & & & & & & & \\
\hline 84 & BB & C4TX & & & & & & & & & & & & & & \\
\hline 118 & BB & C4Tx & & & & & & 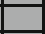 & & ב & & - & & & & 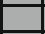 \\
\hline $145^{\star}$ & BB & C4Tx & & & & & & & & & & & & & & \\
\hline 104 & BB & C4TX & & & & & & & & $\square$ & & & & & & \\
\hline $239^{*}$ & BB & C4Tx & & & & & & & & & & & & & & \\
\hline 103 & BB & C4TX & & & & & & & & - & & & & & & \\
\hline 110 & BB & C4Tx & & & & & & 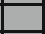 & & 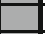 & & & & & & - \\
\hline $202^{\star}$ & BB & C4Tx & & & & & & & & & & & & & & \\
\hline $208^{*}$ & BB & C4Tx & & & & & & & & & & & & & & \\
\hline 108 & BB & C4TX & & & & & & & & & & & & & & \\
\hline $215^{*}$ & BB & C4Tx & & & & & & & & 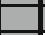 & & & & & & \\
\hline 126 & BB & C4TX & & & & & & 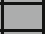 & & 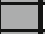 & & & & & & \\
\hline 120 & BB & C4Tx & & & & & & & & & & & & & & \\
\hline 20 & $A B$ & C4TX & & & & & & & & & & & & & & \\
\hline 6 & $A B$ & C4T4 & & & & & & 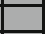 & & $\bar{Z}$ & & 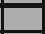 & & & & - \\
\hline 86 & BB & C4T4 & & & & & & & & - & & & & & & \\
\hline 94 & BB & C4T4 & & & & & & 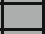 & & $\square$ & & 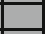 & & & & \\
\hline 87 & BB & C4T4 & & & & & & & & & & & & & & \\
\hline 96 & BB & C4T4 & & & & & & & & 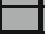 & & & & & & \\
\hline 2 & $A B$ & CxT4 & & & & & & & & & & & & & & \\
\hline 3 & $A B$ & CXT4 & & & & & & & & & & & & & & \\
\hline 23 & $A B$ & CxT4 & & & & & & & & & & & & & & \\
\hline 18 & $A B$ & CxT4 & & & & & & & & & & & & & & \\
\hline $47^{\star}$ & $A B$ & CxT4 & & & & & & & & & & & & & & \\
\hline 99 & BB & CXT4 & & & & & & & & - & & & & & & - \\
\hline 95 & BB & CXT4 & & & & & & 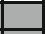 & & & & & & & & \\
\hline 91 & BB & CXT4 & & & & & & & & & & & & & & - \\
\hline 85 & BB & CxT4 & & & & & & & & & & & & & & \\
\hline $221^{*}$ & BB & CxT4 & & & & & & 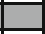 & & 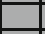 & & & & & & \\
\hline 154 & BB & CxT4 & & & & & & & & & & & & & & \\
\hline 1 & $\mathrm{AA}$ & & & & & & & & & & & & & & & \\
\hline 17 & $A B$ & CxTx & & & & & & & & & & & & & & \\
\hline 25 & $A B$ & CxTx & & & & & & & & & & & & & & \\
\hline $214^{*}$ & BB & CxTx & & & & & & & & & & & & & & \\
\hline 4 & $A B$ & CxTx & & & & & & & & & & & & & & \\
\hline 16 & $A B$ & CxTx & & & & & & & & & & & & & & \\
\hline 15 & $A B$ & CxTx & & & & & & & & & & & & & & \\
\hline 8 & $A B$ & CxTx & & & & & & & & & & & & & & \\
\hline 22 & $A B$ & CxTx & & & & & & & & & & & & & & \\
\hline 9 & $A B$ & CxTx & & & & & & & & & & & & & & \\
\hline $48^{*}$ & $\mathrm{AB}$ & CxTx & & & & & & & & & & & & & & \\
\hline 24 & $A B$ & CxTx & & & & & & & & & & & & & & \\
\hline 12 & $A B$ & CxTx & & & & & & & & & & & & & & \\
\hline 42 & $A B$ & CxTx & & & & & & & & & & & & & & \\
\hline 26 & $A B$ & CxTx & & & & & & & & & & & & & & \\
\hline $54^{*}$ & $A B$ & CxTx & & & & & & & & & & & & & & \\
\hline 43 & $A B$ & CxTx & & & & & & & & & & & & & & \\
\hline 57 & $\mathrm{AB}$ & CxTx & & & & & & & & & & & & & & \\
\hline 46 & $A B$ & CxTx & & & & & & & & & & & & & & \\
\hline 29 & $A B$ & CxTx & & & & & & & & & & & & & & \\
\hline 44 & $A B$ & CxTx & & & & & & & & & & & & & & \\
\hline $59^{*}$ & $A B$ & CxTx & & & & & & & & & & & & & & \\
\hline 32 & $A B$ & CxTx & & & & & & & & & & & & & & \\
\hline $60^{*}$ & $A B$ & CxTx & & & & & & & & & & & & & & \\
\hline 19 & $A B$ & CxTx & & & & & & & & & & & & & & \\
\hline 56 & $A B$ & CxTx & & & & & & & & & & & & & & \\
\hline $74^{*}$ & $A B$ & CxTx & & & & & & & & & & & & & & \\
\hline 13 & $A B$ & CxTx & & & & & & & & & & & & & & \\
\hline $76^{*}$ & $A B$ & CxTx & & & & & & & & & & & & & & \\
\hline 102 & BB & CxTx & & & & & & & & & & & & & & \\
\hline 112 & BB & CxTx & & & & & & & & & & & & & & \\
\hline $240^{*}$ & BB & CxTx & & & & & & & & & & & & & & \\
\hline $241^{*}$ & BB & CxTx & & & & & & & & & & & & & & \\
\hline 88 & BB & CxTx & & & & & & & & & & & & & & \\
\hline 100 & BB & CxTx & & & & & & & & & & & & & & \\
\hline $220^{*}$ & BB & CxTx & & & & & & & & & & & & & & \\
\hline $219^{*}$ & BB & CxTx & & & & & & & & & & & & & & \\
\hline $218^{\star}$ & BB & CxTx & & & & & & & & & & & & & & \\
\hline 101 & BB & CxTx & & & & & & & & & & & & & & \\
\hline $213^{*}$ & BB & CxTx & & & & & & & & & & & & & & \\
\hline 122 & BB & CxTx & & & & & & & & & & & & & & \\
\hline $217^{*}$ & BB & CxTx & & & & & & & & & & & & & & \\
\hline & & & 10 & tal & & луре & 001 & oun & d & 50 & 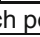 & opul & latio & & & \\
\hline
\end{tabular}


Data analysis and statistical methods

The percentage of individuals carrying each KIR gene in four population groups was determined by direct counting (individuals positive for the gene divided by the individuals tested per population $\times 100$ ). Frequencies of $\mathrm{A}$ and $\mathrm{B}$ haplotypes were calculated using the following formula: group $\mathrm{A}=2 n_{\mathrm{AA}}+n_{\mathrm{AB}} / 2 N$ and group-B $=2 n_{\mathrm{BB}}+n_{\mathrm{AB}} / 2 N$, where $n_{\mathrm{AA}}, n_{\mathrm{AB}}$, and $n_{\mathrm{BB}}$ were the numbers of $\mathrm{AA}, \mathrm{AB}$, and $\mathrm{BB}$ genotypes and $N$ was the total number of individuals tested. Differences between populations in the frequencies of individuals carrying each $K I R$ gene and genotype were estimated by two-tailed Fisher exact probability $(p)$ test, and $p<0.05$ was considered to be statistically significant. The principal components analysis (PCA) of carrier frequency of KIR genes was carried out using the Minitab statistical software.

\section{Results}

Frequency of activating $K I R$ gene carriers differ among Iranian populations

All 16 known KIR genes were detected in each of the native Iranian populations analyzed in this study, and the frequencies of individuals carrying each $K I R$ gene were compared in Table 1. Four framework KIR genes (2DL4, $3 D L 2,3 D L 3$ and $3 D P 1)$ were detected in all 504 individuals analyzed in this study. Overall, the A haplotype associated KIR genes occurred more frequently than the B haplotype associated KIR genes, and their frequencies were comparable between populations. Arab and Azeri revealed similar carrier frequency of each KIR gene but differed considerably from those of Persian and Bakhtiari populations (Table 1). Particularly, the carriers of KIR2DL5, 2DS2, and $2 D S 3$ were more in Arab and Azeri populations compared to the Persian and Bakhtiari populations. The carriers of KIR3DS1 and 2DS5 occurred most frequently in Bakhtiari, and the difference was statistically significant in comparison with Persian population.

The carrier frequency of variably occurring KIR genes in four Iranian populations were compared with those reported in other ethnic populations using the PCA analysis (Fig. 2). Apart from a few outliers, distinct geographic clusters of Africans, Northeast Asians, Mexicans, American Natives, Asian Indians, and Caucasians were noticed on the PCA plot (Fig. 2). Four Iranian populations studied in this paper were mapped somewhat close to each other but considerably isolated from the Northeast Asians, Mexicans, and American Natives. Bakhtiari was plotted within the Caucasian group, while Persian was mapped between Caucasian and African groups. Iranian Arab was more closely clustered to the Maharashtrians, a Western Indian population than the Palestine Arab. Azeri stood isolated and revealed some affinity to the Iranian Arab.

Each Iranian population displays distinct $K I R$ gene content diversity

Within the study panel of 504 unrelated Iranians, we found 78 distinct KIR gene content profiles (genotypes) carrying a different number and combination of 16 KIR genes (Fig. 3). Only $10 \%$ of these genotypes $(1,2,4-7,11$, and 84$)$ were observed in all four Iranian populations, but their combined frequencies were $72.6 \%$ in Persian, 52.1\% in Bakhtiari, $57.9 \%$ in Arab, and 55.9\% in Azeri. Comparison with other ethnic populations revealed that only Caucasian populations carried all of these eight KIR genotypes, and their combined frequencies were comparable to those observed in Iranian populations (Supplement Figure 1a, b). Genotype 1, the homozygous combination of A haplotypes, occurred most frequently in Persian (28.7\%), Bakhtiari (25\%), and Arab (15.8\%; Fig. 3). This is the only genotype found in all ethnic populations investigated to date, and its highest occurrence was reported in the Northeast Asians (Jiang et al. 2005; Whang et al. 2005; Yawata et al. 2002b) (Supplement Figures 1a, b). In Azeri, genotypes 1 and 5 occur at similar frequencies, $14.3 \%$ each. Genotype 5 was the second most common profile in Persian (12.5\%) and Arab (14.5\%), while it occurred only $5.2 \%$ in Bakhtiari populations.

The majority of the genotypes characterized in this study $(43 / 78,55 \%)$ were unique to one of the four Iranian populations, and their combined frequency in the entire study panel was $11.9 \%$ (Fig. 3). Eighteen of these 43 unique genotypes (59-61, 74, 76, 202, 208, 213-215, 217-221, and 239-241) were not reported in other ethnic populations studied previously (Supplement Figures 1a, b). Five genotypes $(36,47,48,54$, and 145) that occurred in more than one Iranian population were also not reported in other ethnic populations. Therefore, a set of 23 KIR genotypes appeared to be unique to the Iranians and are yet to be detected in other populations (Fig. 3 and Supplement Figures 1a, b).

Nearly $75 \%$ of the Iranian Arab and Azeri carry a B KIR haplotype

Of the 78 observed genotypes, 40 were predicted to be the heterozygous combination of $\mathrm{A}$ and $\mathrm{B}$ haplotypes (AB genotypes), 37 were predicted to be the homozygous combination of $\mathrm{B}$ haplotypes (BB genotypes), and one was the homozygous combination of A haplotype (AA genotypes; Fig. 3). Over 55\% of each Iranian population carried AB genotypes with the highest prevalence in Azeri (65.5\%; Table 2). The predicted A haplotypes occurred more frequently than the $\mathrm{B}$ haplotypes in Persian and 
Table 2 Comparison of genotypes, haplotypes and linkage groups in four Iranian populations

\begin{tabular}{|c|c|c|c|c|c|c|c|c|c|c|}
\hline Types & $\begin{array}{l}\text { Persian } \\
\text { (Per) } \\
n=248\end{array}$ & $\begin{array}{l}\text { Bakhtiari } \\
\text { (Bak) } \\
n=96\end{array}$ & $\begin{array}{l}\text { Arab } \\
\text { (Arb) } \\
n=76\end{array}$ & $\begin{array}{l}\text { Azeri } \\
(\text { Aze) } \\
n=84\end{array}$ & $\begin{array}{l}\text { Per vs. } \\
\text { Bak }\end{array}$ & $\begin{array}{l}\text { Per vs. } \\
\text { Arb }\end{array}$ & $\begin{array}{l}\text { Per vs. } \\
\text { Aze }\end{array}$ & $\begin{array}{l}\text { Bak vs. } \\
\text { Arb }\end{array}$ & $\begin{array}{l}\text { Bak vs. } \\
\text { Aze }\end{array}$ & $\begin{array}{l}\text { Arb vs. } \\
\text { Aze }\end{array}$ \\
\hline & $\% \mathrm{~F}(\mathrm{~N})$ & $\% \mathrm{~F}(N)$ & $\% \mathrm{~F}(\mathrm{~N})$ & $\% \mathrm{~F}(\mathrm{~N})$ & & & & & & \\
\hline AA genotype & $28.7(71)$ & $25.0(24)$ & $15.8(12)$ & $14.3(12)$ & & 0.035 & 0.013 & & & \\
\hline BB genotypes & $12.8(32)$ & $18.3(18)$ & $24.6(19)$ & $20.2(17)$ & & 0.0132 & & & & \\
\hline AB genotypes & $58.4(145)$ & $55.8(54)$ & $59.1(45)$ & $65.5(55)$ & & & & & & \\
\hline C4Tx genotypes & $27.4(68)$ & $13.5(13)$ & $31.6(24)$ & $40.5(34)$ & 0.0068 & & 0.028 & & 0.000043 & \\
\hline CxT4 genotypes & $15.3(38)$ & $20.8(20)$ & $11.8(9)$ & $11.9(10)$ & & & & & & \\
\hline C4T4 genotypes & $6.0(15)$ & $9.3(9)$ & $13.1(10)$ & $7.1(6)$ & & & & & & \\
\hline CxTx genotypes & $22.5(56)$ & $31.2(30)$ & $27.3(21)$ & $26.1(22)$ & & & & & & \\
\hline A haplogroups & $57.6(286)$ & $53.1(102)$ & $44.7(68)$ & $46.4(78)$ & & 0.0053 & 0.012 & & & \\
\hline B haplogroups & $42.3(210)$ & $46.8(90)$ & $55.2(84)$ & $53.5(90)$ & & 0.0053 & 0.012 & & & \\
\hline $\mathrm{C} 4$ gene-cluster & $33.5(83)$ & $23.0(22)$ & $44.7(34)$ & $47.6(40)$ & & & 0.026 & 0.0031 & 0.00056 & \\
\hline T4 gene-cluster & $21.4(53)$ & $30.2(29)$ & $25.0(19)$ & $19.0(16)$ & & & & & & \\
\hline
\end{tabular}

The haplotype A and B were determined by using the following formula: group $\mathrm{A}=2 N_{\mathrm{AA}}+N_{\mathrm{AB}} / 2 n$ and group $\mathrm{B}=2 N_{\mathrm{BB}}+N_{\mathrm{AB}} / 2 n$, where $N_{\mathrm{AA}}$, $N_{\mathrm{AB}}$, and $N_{\mathrm{BB}}$ are the numbers of $\mathrm{AA}, \mathrm{AB}$, and $\mathrm{BB}$ genotypes, $n=$ total number of individual.

Bakhtiari, and the extreme of this scenario was reported in Northeast Asians (Jiang et al. 2005; Whang et al. 2005; Yawata et al. 2002b; Supplement Figures 1a, b). In contrast, predicted B haplotypes occurred more frequently in Arab and Azeri compared to the A haplotypes (Table 2). This scenario was previously observed in the natives of America, India, and Australia (Gendzekhadze et al. 2006; Norman et al. 2002; Rajalingam et al. 2008; Toneva et al. 2001).

Nearly half of the Iranian Arab and Azeri populations carried KIR2DS2-2DL2-2DS3-2DL5 gene cluster

All four Iranian populations investigated in these study carried all four subsets of Bx genotypes (CxT4, C4Tx, C4T4, and CxTx), while some ethnic populations studied previously lacked one or more of these subsets (Fig. 4). Within our study panel of 504 Iranians, individuals displaying C4Tx genotypes carried three to five activating $K I R$ genes $(61.9 \%$ carried three activating $K I R \mathrm{~s})$, while individuals displaying CxT4 genotypes carried three to five activating KIR genes (59.0\% carried four activating KIRs), individuals displaying C4T4 genotypes carried five to six activating KIR genes $(75.5 \%$ carried six activating KIRs), and individuals displaying CxTx carried one to four activating $K I R \mathrm{~s}(60.2 \%$ carried two activating KIRs). The Azeri (40.5\%), Arab (31.6\%), and Persian (27.4\%) comprised the higher frequencies of Bx genotypes with $\mathrm{C} 4 \mathrm{Tx}$ configuration compared to any other population studied thus far (Fig. 4). Interestingly, the C4Tx subset was virtually absent from American natives, in whom CxT4 occurred predominantly at a frequency of $70 \%$. In Bakhtiari, the Bx genotypes missing $\mathrm{C} 4$ and $\mathrm{T} 4$ gene clusters (CxTx) were more common compared to the other three Iranian populations. Overall, the constellation of Bx genotypes of Iranians was comparable to Asian Indians and Caucasians but differed substantially from the American natives, Northeast Asians, and Africans (Fig. 4).

\section{Discussion}

Persian and Bakhtiari populations were the descendants of ancient Elamites and Aryans, who arrived in parts of Greater Iran from central Asia in the second millennium BC. Genetic studies describing mitochondrial DNA (mtDNA) sequence variation, $\mathrm{Y}$ chromosome SNP, and HLA gene polymorphism revealed close affinities among Persian, Bakhtiari, and European Caucasian populations (Farjadian et al. 2009; Nasidze et al. 2008). Consistent with the ethnic ancestry and genetic homology, the KIR gene content diversity determined in Bakhtiari and Persian populations were comparable to those reported in Caucasian populations and revealed a balance of A and B KIR haplotypes. Compared to the Bakhtiari and Caucasian populations, the Persian displayed a higher frequency of genotype 5 , which lacks $\mathrm{T} 4$ gene cluster (KIR3DS1, 2DS5 and 2DS1 genes). The genotype 5 occurred most frequently in African populations (Denis et al. 2005; Du et al. 2007; Norman et al. 2002) but is completely absent in American natives (Ewerton et al. 2007; Flores et al. 2007; Gendzekhadze et al. 2006). Unlike the Bakhtiari, a nomadic pastoralist tribal group that straddles the central Zagros Mountains in the province of Khuzistan, the Persian had several historical admixtures, which presumably is the source for the high incidence of genotype 5 . 


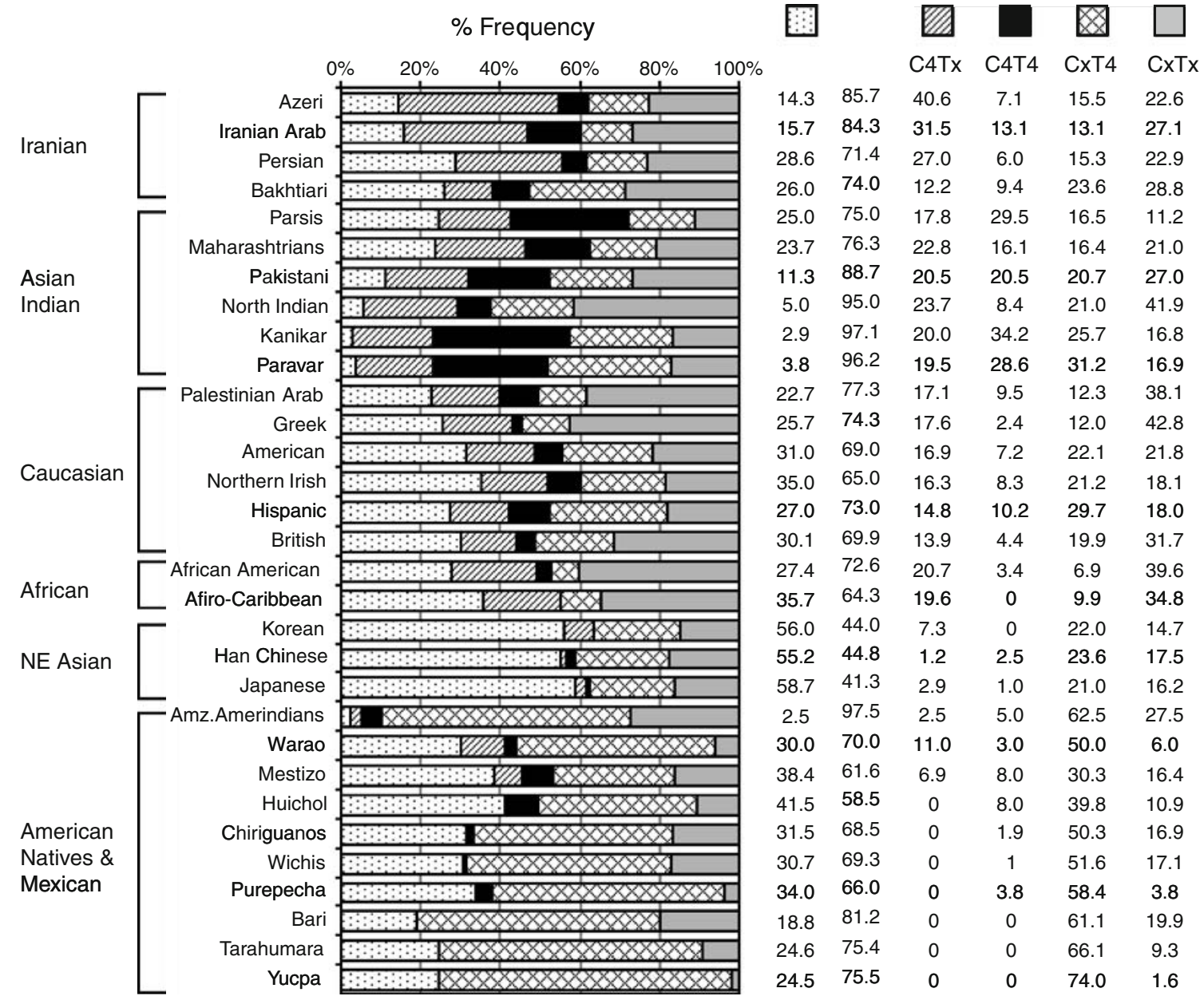

Fig. 4 Subsets of KIR gene content profiles and their frequency in populations. The frequencies of distinct KIR genotype subsets in four Iranian populations are shown in comparison with other previously studied populations. The individuals carrying KIR3DL3-2DL3-2DL12DP1-3DP1-2DL4-3DL1-2DS4-3DL2, a fixed gene content characteristic of A haplotypes, were considered to have $A A$ genotypes (two copies of A haplotypes). Remainders carried Bx genotypes, which

Compared to the geographic neighbors, a greater variability was recently observed at the KIR locus in Indian Parsi, a descendent of Iranian Zoroastrians who emigrated to Western India in the seventh century AD (Kulkarni et al. 2008). Notably, the Indian Parsi had a significantly higher frequency of KIR $3 D S 1$ than did the Northern Indian populations, and possible evolutionary pressure was suggested to retain such high frequency of KIR3DS1 in Indian Parsi. The Y chromosome SNP data showed that the Parsis of India resembled Iranian populations rather than their Indian neighbors (Qamar et al. 2002). KIR gene content diversity data of native Iranian populations was not available at that time for comparison. Herein, we compared the Indian Parsi data with those of other world populations, including four native Iranian populations characterized in comprised either one copy of A haplotype and one copy of B haplotype ( $A B$ genotypes) or two copies of $\mathrm{B}$ haplotypes ( $B B$ genotypes). Based on the presence and absence of two distinct gene clusters $(C 4$, KIR2DS2-2DL2-2DS3-2DL5; T4, KIR3DS1-2DL5-2DS5-2DS1), the $\mathrm{Bx}$ genotype carries were divided into four subsets: C4Tx (presence of C4 and absence of T4), CxT4 (absence of C4 and presence of T4), C4T4 (presence of both C4 and T4), CxTx (absence of both C4 and T4)

this study and three Southern Indian tribal populations studied recently (Rajalingam et al. 2008). The analyses revealed that the KIR gene content profiles of Indian Parsi were more comparable to the Indian populations than the native Iranians. Specifically, $29.5 \%$ of Parsis of India were the carriers of C4T4 Bx genotypes, while only $6 \%$ of the Persian displayed this constellation. Consequently, the Parsis of India comprised more activating KIR genes than the Iranian Persian. It is intriguing to postulate that the Parsis of India gained the $\mathrm{C} 4$ (KIR2DS2-2DL2-2DS3-2DL5) and $\mathrm{T} 4$ (KIR3DS1-2DL5-2DS5-2DS1) gene clusters by accumulating the activating KIR genes during their migration to India or following their settlement in India through population bottlenecks and episodes of selection by infectious disease. 
The Iranian Arab population mainly occupies the Khuzestan province of Iran. Historical evidence indicates that their ancestors, Arab tribes such as the Bakr bin Wael and Bani Tamim, entered Iran in the seventh century AD, although there may have been an earlier Arabic presence in Iran (Morony 2006). The mtDNA HV1 sequence polymorphisms and Y chromosome bi-allelic diversity showed that the North African Arabs were far more distant genetically from the Iranian Arab (Nasidze et al. 2008). Moreover, the Iranian Arab shared close relatedness to the neighboring geographic groups. Haplogroups $\mathrm{J} 2$ and $\mathrm{G}$ were especially intriguing because they were found in very high frequencies in Bakhtiari and Iranian Arab (Nasidze et al. 2008). Despite the genetic affinity and geographic proximity, the Iranian Arab carried the highest frequency of B haplotypes among the four Iranian populations, while the Bakhtiari displayed a balance of A and $\mathrm{B}$ haplotypes. Intriguingly, the KIR genomic diversity of Iranian Arab was more similar to the Indian Maharashtrians and Iranian Azeri than the Palestinian Arab. Particularly, the Iranian Arab, Azeri, and Indian Maharashtrians displayed a comparable constellation of $\mathrm{Bx}$ genotypes with high frequencies of the $\mathrm{C} 4$ gene cluster (KIR2DS2-2DL2-2DS3-2DL5) compared to the Palestinian Arab (Supplement Figure 1b).

Comparative analyses of KIR data from world populations revealed a link between the prehistoric human migrations and the evolution of two groups of KIR haplotypes distinguished by their content of activating KIR genes (Rajalingam et al. 2008). The natives of America, India, and Australia, who had extensive prehistoric migrations, carried high frequencies of $B$ haplotypes, and presumably, they acquired these activating $K I R$ enriched haplotypes to survive different environmental challenges on their journey. The natives of India and Australia were considered to be the most ancient human dispersal out of Africa, which happened about 60,000 years ago, most likely via the tropical coast of the Arabian peninsula, India, Southeast Asia, and Australia. An increasing frequency cline of B haplotypes from Arabs (51.8\% in Palestinian Arab and 55.3\% in Iranian Arab) toward Pakistani (60.5\%), Indian tribes ( $70 \%)$, and Australian aborigines ( $>70 \%)$ suggests that the expansion of B haplotypes in the most ancient migratory group began in Arabian peninsula that bridges Africa and Asia.

Azeri, one of the major Iranian ethnic populations that speaks an Indo-European language, has mixed genetic (mtDNA and Y chromosome) and cultural elements of Persian, Caucasian, and Turkic people (Ashrafian-Bonab et al. 2007; Nasidze et al. 2003; Quintana-Murci et al. 2004). However, by displaying a dominance in B KIR haplotypes that carry $\mathrm{C} 4$ gene cluster (KIR2DS2-2DL2-2DS3-2DL5), the Azeri population was more related to Iranian and Indian populations. It is not clear whether a local specific selection or a racial admixture is responsible for the dominance of B haplotypes in Azeri. In conclusion, the genetic pool supplied by the waves of prehistoric migration, subsequent racial admixture, and local-specific selection appeared to be the force that determined the KIR diversity in modern Iranians.

Acknowledgments This work was supported by the start-up funds from the UCLA Department of Pathology and Laboratory Medicine (to R.R.) and by Shiraz Institute for Cancer Research (grant number 85-3073 to A.G.). Elham Ashouri was supported by a fellowship from the Ministry of Health and Medical Education, The Islamic Republic of Iran. The authors thank Dr. Samadi, Dr. Shalbafzadeh, Dr. Afrasiabi, Dr. Dehbozorgian, Miss Chenari, Mr. Saki, Mr. Naeimi, Mr. Aliparsti, and Mr. Malekzadeh for their help in sample collection.

Open Access This article is distributed under the terms of the Creative Commons Attribution Noncommercial License which permits any noncommercial use, distribution, and reproduction in any medium, provided the original author(s) and source are credited.

\section{References}

Ashouri E, Ghaderi A, Reed EF, Rajalingam R (2009) A novel duplex SSP-PCR typing method for KIR gene profiling. Tissue Antigens 73. doi:10.1111/j.1399-0039.2009.01259.x

Ashrafian-Bonab M, Lawson Handley LJ, Balloux F (2007) Is urbanization scrambling the genetic structure of human populations? A case study. Heredity 98:151-156. doi:10.1038/sj. hdy. 6800918

Denis L, Sivula J, Gourraud PA, Kerdudou N, Chout R, Ricard C, Moisan JP, Gagne K, Partanen J, Bignon JD (2005) Genetic diversity of KIR natural killer cell markers in populations from France, Guadeloupe, Finland, Senegal and Reunion. Tissue Antigens 66:267-276. doi:10.1111/j.1399-0039.2005.00473.x

Du Z, Gjertson DW, Reed EF, Rajalingam R (2007) Receptor-ligand analyses define minimal killer cell Ig-like receptor (KIR) in humans. Immunogenetics 59:1-15. doi:10.1007/s00251-006-0168-4

Du Z, Sharma SK, Spellman S, Reed EF, Rajalingam R (2008) KIR2DL5 alleles mark certain combination of activating KIR genes. Genes Immun 9:470-480. doi:10.1038/gene.2008.39

Ewerton PD, Leite Mde M, Magalhaes M, Sena L, Melo dos Santos EJ (2007) Amazonian Amerindians exhibit high variability of KIR profiles. Immunogenetics 59:625-630. doi:10.1007/s00251007-0229-3

Farjadian S, Ota M, Inoko H, Ghaderi A (2009) The genetic relationship among Iranian ethnic groups: an anthropological view based on HLA class II gene polymorphism. Mol Biol Rep. doi:10.1007/s11033-008-9403-4

Flores AC, Marcos CY, Paladino N, Capucchio M, Theiler G, Arruvito L, Pardo R, Habegger A, Williams F, Middleton D, Fainboim L (2007) KIR genes polymorphism in Argentinean Caucasoid and Amerindian populations. Tissue Antigens 69:568576. doi:10.1111/j.1399-0039.2007.00824.x

Gendzekhadze K, Norman PJ, Abi-Rached L, Layrisse Z, Parham P (2006) High KIR diversity in Amerindians is maintained using few gene-content haplotypes. Immunogenetics 58:474-480. doi:10.1007/s00251-006-0108-3

Gutierrez-Rodriguez ME, Sandoval-Ramirez L, Diaz-Flores M, Marsh SG, Valladares-Salgado A, Madrigal JA, Mejia-Arangure JM, Garcia CA, Huerta-Zepeda A, Ibarra-Cortes B, Ortega-Camarillo C, Cruz M (2006) KIR gene in ethnic and Mestizo populations from Mexico. Hum Immunol 67:85-93. doi:10.1016/j.humimm.2005.11.007

Hou L, Steiner NK, Chen M, Belle I, Kubit AL, Ng J, Hurley CK (2008) Limited allelic diversity of stimulatory two-domain killer cell immunoglobulin-like receptors. Hum Immunol 69:174-178. doi:10.1016/j.humimm.2008.01.009 
Hsu KC, Liu XR, Selvakumar A, Mickelson E, O’Reilly RJ, Dupont B (2002) Killer Ig-like receptor haplotype analysis by gene content: evidence for genomic diversity with a minimum of six basic framework haplotypes, each with multiple subsets. J Immunol 169:5118-5129

Jiang K, Zhu FM, Lv QF, Yan LX (2005) Distribution of killer cell immunoglobulin-like receptor genes in the Chinese Han population. Tissue Antigens 65:556-563. doi:10.1111/j.1399-0039.2005.00412.x

Khakoo SI, Carrington M (2006) KIR and disease: a model system or system of models? Immunol Rev 214:186-201. doi:10.1111/ j.1600-065X.2006.00459.X

Kulkarni S, Single RM, Martin MP, Rajalingam R, Badwe R, Joshi N, Carrington M (2008) Comparison of the rapidly evolving KIR locus in Parsis and natives of India. Immunogenetics 60:121129. doi:10.1007/s00251-008-0279-1

Lanier LL (2005) NK cell recognition. Annu Rev Immunol 23:225274. doi:10.1146/annurev.immunol.23.021704.115526

Lee YC, Chan SH, Ren EC (2008) Asian population frequencies and haplotype distribution of killer cell immunoglobulin-like receptor (KIR) genes among Chinese, Malay, and Indian in Singapore. Immunogenetics 60:645-654. doi:10.1007/s00251-008-0321-3

Martin AM, Kulski JK, Gaudieri S, Witt CS, Freitas EM, Trowsdale J, Christiansen FT (2004) Comparative genomic analysis, diversity and evolution of two KIR haplotypes A and B. Gene 335:121131. doi:10.1016/j.gene.2004.03.018

McQueen KL, Dorighi KM, Guethlein LA, Wong R, Sanjanwala B, Parham P (2007) Donor-recipient combinations of group A and B KIR haplotypes and HLA class I ligand affect the outcome of HLA-matched, sibling donor hematopoietic cell transplantation. Hum Immunol 68:309-323. doi:10.1016/j.humimm.2007.01.019

Middleton D, Meenagh A, Gourraud PA (2007) KIR haplotype content at the allele level in 77 Northern Irish families. Immunogenetics 59:145-158. doi:10.1007/s00251-006-0181-7

Morony M (2006) Arab II: Arab conquest of Iran. The encyclopaedia Iranica. Center for Iranian Studies, Columbia University, New York

Nasidze I, Quinque D, Rahmani M, Alemohamad SA, Stoneking M (2008) Close genetic relationship between Semitic-speaking and Indo-European-speaking groups in Iran. Ann Hum Genet 72:241-252. doi:10.1111/j.1469-1809.2007.00413.x

Nasidze I, Sarkisian T, Kerimov A, Stoneking M (2003) Testing hypotheses of language replacement in the Caucasus: evidence from the Y-chromosome. Hum Genet 112:255-261

Niokou D, Spyropoulou-Vlachou M, Darlamitsou A, StavropoulosGiokas C (2003) Distribution of killer cell immunoglobulin-like receptors in the Greek population. Hum Immunol 64:1167-1176. doi:10.1016/j.humimm.2003.08.100

Norman PJ, Carrington CV, Byng M, Maxwell LD, Curran MD, Stephens HA, Chandanayingyong D, Verity DH, Hameed K, Ramdath DD, Vaughan RW (2002) Natural killer cell immunoglobulin-like receptor (KIR) locus profiles in African and South Asian populations. Genes Immun 3:86-95. doi:10.1038/sj. gene. 6363836

Norman PJ, Stephens HA, Verity DH, Chandanayingyong D, Vaughan RW (2001) Distribution of natural killer cell immunoglobulinlike receptor sequences in three ethnic groups. Immunogenetics 52:195-205. doi:10.1007/s002510000281

Parham P (2005) MHC class I molecules and KIRs in human history, health and survival. Nat Rev Immunol 5:201-214. doi:10.1038/nri1570

Qamar R, Ayub Q, Mohyuddin A, Helgason A, Mazhar K, Mansoor A, Zerjal T, Tyler-Smith C, Mehdi SQ (2002) Y-chromosomal DNA variation in Pakistan. Am J Hum Genet 70:1107-1124. doi:10.1086/339929

Quintana-Murci L, Chaix R, Wells RS, Behar DM, Sayar H, Scozzari R, Rengo C, Al-Zahery N, Semino O, Santachiara-Benerecetti AS, Coppa A, Ayub Q, Mohyuddin A, Tyler-Smith C, Qasim Mehdi S, Torroni A, McElreavey K (2004) Where west meets east: the complex mtDNA landscape of the southwest and Central Asian corridor. Am J Hum Genet 74:827-845. doi: $10.1086 / 383236$

Rajalingam R, Du Z, Meenagh A, Luo L, Kavitha VJ, PavithraArulvani R, Vidhyalakshmi A, Sharma SK, Balazs I, Reed EF, Pitchappan RM, Middleton D (2008) Distinct diversity of KIR genes in three southern Indian populations: comparison with world populations revealed a link between KIR gene content and pre-historic human migrations. Immunogenetics 60:207-217. doi:10.1007/s00251-008-0286-2

Rajalingam R, Krausa P, Shilling HG, Stein JB, Balamurugan A, McGinnis MD, Cheng NW, Mehra NK, Parham P (2002) Distinctive KIR and HLA diversity in a panel of north Indian Hindus. Immunogenetics 53:1009-1019. doi:10.1007/s00251001-0425-5

Santin I, de Nanclares GP, Calvo B, Gaafar A, Castano L, Bilbao JR (2006) Killer cell immunoglobulin-like receptor (KIR) genes in the Basque population: association study of KIR gene contents with type 1 diabetes mellitus. Hum Immunol 67:118-124. doi:10.1016/j.humimm.2006.02.036

Shilling HG, Guethlein LA, Cheng NW, Gardiner CM, Rodriguez R, Tyan D, Parham P (2002) Allelic polymorphism synergizes with variable gene content to individualize human KIR genotype. J Immunol 168:2307-2315

Single RM, Martin MP, Gao X, Meyer D, Yeager M, Kidd JR, Kidd KK, Carrington M (2007) Global diversity and evidence for coevolution of KIR and HLA. Nat Genet 39:1114-1119. doi:10.1038/ng2077

Toneva M, Lepage V, Lafay G, Dulphy N, Busson M, Lester S, Vu-Trien A, Michaylova A, Naumova E, McCluskey J, Charron D (2001) Genomic diversity of natural killer cell receptor genes in three populations. Tissue Antigens 57:358-362. doi:10.1034/j.13990039.2001.057004358.x

Trinchieri G (1989) Biology of natural killer cells. Adv Immunol 47:187-376. doi:10.1016/S0065-2776(08)60664-1

Uhrberg M, Valiante NM, Shum BP, Shilling HG, Lienert-Weidenbach K, Corliss B, Tyan D, Lanier LL, Parham P (1997) Human diversity in killer cell inhibitory receptor genes. Immunity 7:753763. doi:10.1016/S1074-7613(00)80394-5

Velickovic M, Velickovic Z, Dunckley H (2006) Diversity of killer cell immunoglobulin-like receptor genes in Pacific Islands populations. Immunogenetics 58:523-532. doi:10.1007/s00251006-0124-3

Vilches C, Parham P (2002) KIR: diverse, rapidly evolving receptors of innate and adaptive immunity. Annu Rev Immunol 20:217251. doi:10.1146/annurev.immunol.20.092501.134942

Whang DH, Park H, Yoon JA, Park MH (2005) Haplotype analysis of killer cell immunoglobulin-like receptor genes in 77 Korean families. Hum Immunol 66:146-154. doi:10.1016/j.humimm.2004.10.013

Wilson MJ, Torkar M, Haude A, Milne S, Jones T, Sheer D, Beck S, Trowsdale J (2000) Plasticity in the organization and sequences of human KIR/ILT gene families. Proc Natl Acad Sci U S A 97:4778-4783. doi:10.1073/pnas.080588597

Witt CS, Dewing C, Sayer DC, Uhrberg M, Parham P, Christiansen FT (1999) Population frequencies and putative haplotypes of the killer cell immunoglobulin-like receptor sequences and evidence for recombination. Transplantation 68:1784-1789. doi:10.1097/ 00007890-199912150-00024

Yawata M, Yawata N, Abi-Rached L, Parham P (2002a) Variation within the human killer cell immunoglobulin-like receptor (KIR) gene family. Crit Rev Immunol 22:463-482

Yawata M, Yawata N, McQueen KL, Cheng NW, Guethlein LA, Rajalingam R, Shilling HG, Parham P (2002b) Predominance of group A KIR haplotypes in Japanese associated with diverse NK cell repertoires of KIR expression. Immunogenetics 54:543-550. doi:10.1007/s00251-002-0497-x 